\title{
Bacteriocins and Phages Produced by Serratia marcescens
}

\author{
By HELENE E. PRINSLOO \\ Research Institute for Plant Protection, Department of Agricultural \\ and Technical Services, Pretoria, South Africa
}

(Received 11 May 1966)

\begin{abstract}
SUMMARY
One hundred and thirty-nine strains of Serratia marcescens were investigated for bacteriocin and phage production. Two types of bacteriocins were detected. Group A were all active on serratias and were produced by 71 strains. Some of these bacteriocins also attacked Salmonella, Escherichia and Aerobacter strains. They were produced spontaneously in broth, and higher titres were produced by induction with ultraviolet (u.v.) radiation. These bacteriocins are divided into eight subgroups by their spectrum of activity and resistant mutants of indicator strains. Group B bacteriocins are not active on serratias. Their action is restricted to escherichias, hafnias and aerobacters. Mutant bacteria resistant to any one of these $\mathbf{B}$ agents are resistant to all other $\mathbf{B}$ bacteriocins. The $\mathbf{B}$ agents are serologically similar and are produced in broth by 54 strains. They are produced spontaneously and higher titres are produced after u.v. induction. With one exception the B bacteriocins may be identical. Thirty-five strains produced both types of bacteriocins. The $\mathbf{A}$ bacteriocins are resistant to chloroform, trypsin and the proteolytic enzymes of certain organisms, are heat-stable and non-dialysable. Group B bacteriocins are heat-labile, nondialysable and inactivated by chloroform and the above enzymes. Agents $A$ and $B$ differ from colicins. Thirty-seven of the strains were lysogenic for Serratia species and 19 of the phages productively lysed Salmonella species. Although overlaps did occur it was always possible to distinguish the bacteriocins from the corresponding temperate phage produced by a strain, by means of their spectra of activity.
\end{abstract}

\section{INTRODUCTION}

Strains of Serratia marcescens may produce at least three antibacterial substances. Fuller \& Horton (1950) described an antibiotic-like substance, marcescin, which has an inhibitory action on Corynebacterium diphtheriae and Staphylococcus aureus. Hamon \& Peron (1961) and Mandel \& Mohn (1962) described bacteriocinogenic activity among strains of $S$. marcescens; Prinsloo \& Coetzee (1964) found 15 of 31 strains of $\boldsymbol{S}$. marcescens to be lysogenic for other $\boldsymbol{S}$. marcescens and Salmonella strains. Fredericq (1954) showed that colicinogenic factors were transmissible to strains of other Escherichia coli and shigellas while Amati \& Ozeki (1962) transmitted colicinogenic factors $\mathrm{E}_{1}, \mathrm{E}_{2}$ from Salmonella typhimurium to serratias. In view of the genetic importance of phage and bacteriocinogenic factors, these agents were investigated in a series of 139 Serratia marcescens strains. 


\section{METHODS}

Bacteria. These comprised 15 strains of Serratia marcescens obtained from the National Collection of Type Cultures, NCTC 1377, 2446, 2847, 4618, 8015, 3084, 8706, 8900, 9493, 9940, 9741, 9743, 10036, 10211, 4619; one American Type Culture strain ATCC 9986; 123 local strains isolated from human and insect sources. The 123 strains could be differentiated by lysogenicity and phage-susceptibility (Prinsloo \& Coetzee, 1964; H. E. Prinsloo, unpublished). The strains were biochemically typical (Martinec \& Kocur, 1961) except for sm 8 which was maltose-negative, and SM 52 which was sucrose-negative, and were either non-pigmented or pigmented. Standard colicinogenic strains which produced colicins A to K, V and S 1-4 were obtained from Professor P. Fredericq. The indicator used for colicins was Escherichia coli ø, while the following bacterial strains were used to determine the spectrum of activity of the antibacterial agents produced by $S$. marcescens: all the Serratia strains, the colicinogenic strains of Fredericq, Hafnia spp $\left(\mathrm{H}_{1-6}\right)$, Aerobacter aerogenes $\left(\mathrm{x}_{1-7}\right)$, Alcaligenes faecalis (NCTC 8769), Proteus hauseri, $\boldsymbol{P}$. morganii, $\boldsymbol{P}$. rettgeri and the providence cultures previously used (Coetzee, $1963 \mathrm{a}$ ). In addition, $12 \mathrm{Salmonella}$ typhi strains of different Vi phage types were used as well as 28 Salmonella serotypes belonging to each of the Kauffman-White groups and 10 unclassified strains, 24 Shigella strains of different serotypes, 10 strains of Staphylococcus pyogenes, 10 Bacillus strains, and one toxigenic Corynebacterium diphtheriae. The following proteolytic organisms were used: Bacillus cereus strain в 2, S. marcescens sm 1, 5, 8, 9, 11, 41, 52, NCTC 2847, P. mirabilis strain 13-0 (Coetzee, 1963b). The bacteria were maintained on nutrient agar slopes at $4 i^{\circ}$. Cultures were incubated at $32^{\circ}$.

Media. Oxoid No. 2 nutrient broth was used. The solid media contained $1 \cdot 1 \%$ $(\mathrm{w} / \mathrm{v})$ agar, $0.8 \% \mathrm{NaCl}(\mathrm{w} / \mathrm{v}), \mathbf{1} \cdot 3 \%(\mathrm{w} / \mathrm{v})$ tryptone, $0.2 \%(\mathrm{w} / \mathrm{v})$ glucose. The soft top layer contained $0.6 \%(\mathrm{w} / \mathrm{v})$ agar. When $s t r-r$ mutants were used as indicators for bacteriocins streptomycin sulphate $1 \mathrm{mg} . / \mathrm{ml}$. was added to media.

Ultraviolet radiation source. A $30 \mathrm{~W}$. Hanovia germicidal lamp, which delivered more than $80 \%$ of its output at a wavelength of $2537 \AA$, was used at a distance of 12 inches.

Procedures. Streptomycin-resistant mutants of sensitive bacterial strains were selected by plating about $10^{11}$ organisms on streptomycin agar. After incubation resistant colonies were restreaked on this medium for purification. The optimal temperature for bacteriocin production was determined by incubating $0.1 \mathrm{ml}$. of overnight cultures of SM $1,5,8,9,11,41,91,99$, ATCC 9986, NCTC 2847 in $7 \cdot 5 \mathrm{ml}$. broth for $25 \mathrm{hr}$ at $20^{\circ}, 23^{\circ}, 26^{\circ}, 28^{\circ}, 30^{\circ}, 34^{\circ}, 37^{\circ}$. After centrifugation, dilutions of the clear supernatant fluids were spotted on streptomycin agar which had previously been spread with the streptomycin-resistant indicator in a soft agar overlay; the plates were incubated at $32^{\circ}$.

Induction by ultraviolet radiation. Five ml. samples of broth cultures were u.v.irradiated in Petri dishes in the dark; $0.1 \mathrm{ml}$. of the u.v.-irradiated suspensions was then added to $7.5 \mathrm{ml}$. broth and incubated in the dark at $30^{\circ}$ for $24 \mathrm{hr}$. The general phage techniques used were those of Adams (1959). Turbidity measurements were made with a Fisher Electrophotometer, with a $425 \mathrm{~m} \mu$ filter. Colonies resistant to inhibitory substances were picked from the zones of inhibition in the lawns of growth. The bacterial action of inhibitory substances was determined by subcultur- 
ing from the clear zones to nutrient agar; when no growth occurred it was taken that the substances were bactericidal. Heat inactivation was studied by heating $1 \mathrm{ml}$. samples of the inhibitory solutions in a water bath at various temperatures for various intervals of time, and then testing for activity.

Inactivation by trypsin was determined by adding $\mathbf{0 . 2} \mathrm{ml}$. of a $1 \%(\mathrm{w} / \mathrm{v})$ trypsin solution (British Drug Houses) in a $0 \cdot 1 \mathrm{M}$-phosphate buffer ( $\mathrm{pH} 7 \cdot 4$ ) to $1 \mathrm{ml}$. of bacteriocin solution. The mixture was kept at $37^{\circ}$ for $1.5 \mathrm{hr}$ and then tested for activity of the bacteriocin.

Many Serratia strains are lysogenic (Prinsloo \& Coetzee, 1964) and bacteriocin preparations may therefore also contain phage. Bacteriocins were demonstrated by their greater diffusibility as follows. Clear supernatant fluids obtained after induction were placed in holes in nutrient agar. After $18 \mathrm{hr}$ at room temperature the surface was covered with soft agar which contained the indicator organism and incubated. Samples were then also taken from the periphery of these zones of inhibition, suspended in $1 \mathrm{ml}$. broth and retested. The absence of transferable activity confirmed the bacteriocin-like nature of the substances. Bacteriocin antiserum was obtained by injection of $2 \mathrm{ml}$. bacteriocin broth solution (not necessarily free from phage) subcutaneously into rabbits twice weekly for 6 weeks. Neutralization tests with the antisera were done by mixing $0.1 \mathrm{ml}$. antiserum with $0.9 \mathrm{ml}$. bacteriocin solution. The mixture was kept at $37^{\circ}$ for $1 \mathrm{hr}$ and then tested for activity. Controls had normal rabbit serum in place of antiserum. Chloroform sensitivity was tested by adding $0.5 \mathrm{ml}$. chloroform to $2.5 \mathrm{ml}$. antibiotic solution; the mixture was shaken and left at room temperature for $15 \mathrm{~min}$. After the bacteriocin solution was decanted and bubbled with sterile air at $37^{\circ}$ to free it from chloroform, its activity was tested.

Chloroform sterilization of antibacterial solutions was not generally used. Instead, clear supernatant fluids from u.v.-induced suspension were spotted on streptomycinresistant indicator organisms on streptomycin agar.

Inactivation of the antibacterial solutions by gelatin-liquefying strains was tested by the method of Wahba (1963). Proteolytic strains were grown in nutrient agar for $\mathbf{2 4} \mathrm{hr}$ at $\mathbf{3 2}^{\circ}$. Bacteriocin solutions were spotted over the proteolytic strains and were incubated overnight. The plates were covered with str-r indicator organisms in the top layer containing streptomycin. The presence of bacteriocins in broth cultures of SM 1, 8, 9, 11, 41, 91, 99, NCTC 2847 incubated at $30^{\circ}$ were tested after 24, 72, $144 \mathrm{hr}$ for autodestruction by autologous proteloytic enzymes. Bacteriocin solutions were dialysed against distilled water for $24 \mathrm{hr}$ at room temperature.

The lysogeny of Serratia strains was investigated as before (Prinsloo \& Coetzee, 1964) and all strains were tested for phage susceptibility. Attempts were made to lysogenize susceptible Salmonella strains with serratia phages. These procedures and also tests for immunity of clones to superinfection with phage were done according to Levine (1957). Dilutions of phage suspension and host bacteria were plated on nutrient agar with phage antiserum. Individual colonies were tested for phage production and resistance to phage. Phage multiplicities of input of 1,5 and 10 were used; the experiments were done at $32^{\circ}$. 


\section{RESULTS}

According to the spectrum of activity of the bacteriocins two groups were distinguished.

Group $A$. These agents resembled bacteriocins in their narrow spectrum of activity and were produced by 71 strains in titres up to $1 / 100$. Some strains were more active in the production of bacteriocins than others. They were all active on serratias and some of them were also active against some salmonella strains and Escherichia coli.

Group $B$. These substances were not active on Serratia marcescens. They have a spectrum of activity restricted to Escherichia coli, Aerobacter aerogenes and the Hafnia species. They are produced by 54 strains. Titres up to 1/100 were obtained. Strain ATCC 9986 differed in that its bacteriocin did not attack $E$. coli strains.

\section{Table 1. Bacteriocinogenic activity of Serratia marcescens strains}

\begin{tabular}{|c|c|c|c|}
\hline A group activity & $\begin{array}{l}A \text { and } B \text { group } \\
\text { activity }\end{array}$ & B group & $\begin{array}{l}\text { Non- } \\
\text { bacteriocinogenic }\end{array}$ \\
\hline \multicolumn{4}{|c|}{ Strain no. } \\
\hline $\begin{array}{l}48,52,53,58,59, \\
73,101,102,108, \\
107,108,109,112, \\
118,119,120,121, \\
122,123,124,129, \\
131,132,133,134, \\
135,136,137,144, \\
146,148,156,176, \\
177, \text { NCTC } 8015, \\
9741\end{array}$ & $\begin{array}{l}1,4,6,7,9,11, \\
19,37,38,41,42, \\
43,44,91,99,111, \\
116,125,127,139, \\
140,149,150,157, \\
160,170,174,190, \\
200,207, \text { ATCC } \\
9986, \text { NCTC 1377, } \\
2847,9940,10211\end{array}$ & $\begin{array}{l}3,5,10,12,14,15, \\
18,89,40,45,47 \\
74,75,130,161, \\
172, \text { NCTC } 2446, \\
9493,9743\end{array}$ & $\begin{array}{l}51,56,57,60,61, \\
62,63,64,65, \\
66,67,68,69,70, \\
71,72,76,77,78, \\
79,104,105,106, \\
108,113,114,115, \\
117,138,143,146, \\
159,171,178,180, \\
184,185,194,201, \\
202,205,208,209, \\
\text { NCTC 8900, 3084, } \\
4618,8706,10036, \\
4619\end{array}$ \\
\hline
\end{tabular}

The agents of groups $\mathrm{A}$ and $\mathrm{B}$ were produced in broth at an optimum temperature of $30^{\circ}$. Bacteriocins were also produced at $20,23,26,28,34^{\circ}$, and most strains did not produce bacteriocins at $37^{\circ}$. Group $B$ bacteriocins were produced spontaneously in broth but the concentration was greatly increased by ultraviolet irradiation. Suspensions were u.v.-irradiated for periods of from $5 \mathrm{sec}$. to $10 \mathrm{~min}$. In no instance was mass lysis observed and turbidity measurements increased steadily with time. This also applied to strains which were both bacteriocinogenic and lysogenic. It was found that 45 sec. of u.v.-irradiation of an overnight broth culture incubated in broth in the dark usually yielded maximal titres. Only 32 of the 73 bacteriocinogenic serratia strains investigated by Hamon \& Peron (1961) produced detectable bacteriocins in agar. The remaining 41 strains only liberated bacteriocins after u.v.-induction of broth cultures. As seen in Table 1, 35 strains which produced A agents also produced $B$ agents. This double activity was determined by the use of appropriate indicator organisms. Thus in the case of the A bacteriocins Serratia indicators were used, and for group $\mathbf{B}$ agents Hafnia indicators. Overnight as well as exponentially growing cultures were used. With strains which produced both $\mathbf{A}$ and $\mathbf{B}$ bacteriocins the $\mathbf{B}$ agent was usually detectable in supernatant fluids about $\mathbf{l ~} \mathrm{hr}$ before $\mathbf{A}$ activity appeared. In no instance did a strain produce an agent which 
was active on itself like the colicin which Ryan, Fried \& Mukoi (1955) encountered, and the strains of Pasteurella pseudotuberculosis and $\boldsymbol{P}$. pestis which are pestinogenic for pesticin II were also sensitive to it.

The bacteriocins were bactericidal. The bacteriocins of group A were resistant to trypsin and chloroform and withstood $60^{\circ}$ for $30 \mathrm{~min}$. They were non-dialysable. These agents were resistant to the action of proteolytic organisms but the bacteriocin liberated by SM 52 was thermolabile, sensitive to trypsin, and completely inactivated by proteolytic organisms. Group B substances were sensitive to trypsin and chloroform and inactivated at $60^{\circ}$ for $30 \mathrm{~min}$. They were non-dialysable. These B substances were inactivated by autologous proteolytic enzymes when tested by the method of Wahba (1963). In broth cultures the titre of the $B$ bacteriocins was decreased after $72 \mathrm{hr}$ incubation and could not be demonstrated after $144 \mathrm{hr}$.

Table 2. Subdivision of $\boldsymbol{A}$ group bacteriocins of Serratia marcescens

\begin{tabular}{|c|c|c|c|c|c|c|c|c|c|}
\hline \multirow{4}{*}{$\begin{array}{l}\text { Bacteriocin } \\
\text { produced by }\end{array}$} & & & & & \multicolumn{4}{|c|}{$\begin{array}{c}\text { Mutants of } \\
\text { indicator strains }\end{array}$} & \multirow{4}{*}{$\begin{array}{l}\text { Sub- } \\
\text { divi- } \\
\text { sion }\end{array}$} \\
\hline & \multicolumn{4}{|c|}{$\begin{array}{l}\text { Indicator strains } \\
\text { of } S . \text { marcescens }\end{array}$} & \multirow{2}{*}{\multicolumn{2}{|c|}{$\overbrace{\begin{array}{c}\text { SM. } 42 \\
\text { resistant to }\end{array}}$}} & \multirow{2}{*}{\multicolumn{2}{|c|}{$\begin{array}{l}\text { sM. } 8 \text { re- } \\
\text { sistant to }\end{array}$}} & \\
\hline & \multirow[b]{2}{*}{ sM. 42} & \multirow[b]{2}{*}{8} & \multirow{2}{*}{$\begin{array}{l}\text { NCTC } \\
8900\end{array}$} & \multirow[b]{2}{*}{$\mathbf{1}$} & & & & & \\
\hline & & & & & 41 & $41+8$ & 11 & 99 & \\
\hline $1,6,125,127$ & +++ & - & $+t+$ & - & +++ & +++ & - & - & $\mathbf{A}_{1}$ \\
\hline $\begin{array}{l}9,91,199,122,139 \\
177,200, \text { NCTC } 10211\end{array}$ & $++t$ & - & • & - & +++ & +++ & - & - & $\mathbf{A}_{2}$ \\
\hline $\begin{array}{l}8,44,48,101,116,121 \\
123\end{array}$ & +++ & $\cdot$ & - & - & +++ & - & - & - & $\mathbf{A}_{3}$ \\
\hline $\begin{array}{l}11,38,43,58,73,99 \\
137,144,146,148,157, \\
176,190,207\end{array}$ & - & $++t$ & $+t+$ & - & - & - & - & - & $\mathbf{A}_{4}$ \\
\hline $41,136,140$ & +++ & $+t+$ & +++ & +++ & - & - & - & . & $\mathbf{A}_{\mathbf{5}}$ \\
\hline NCTC 2847, 37 & $+t+$ & +++ & $++t$ & - & $+t+$ & $++t$ & - & - & $\mathbf{A}_{6}$ \\
\hline ATCC 9986 & + & • & ++ & $+t+$ & • & • & - & . & $\mathbf{A}_{7}$ \\
\hline 52 & + & + & . & +++ & . & . & . & . & $\mathbf{A}_{8}$ \\
\hline
\end{tabular}

\section{Subdivision of antibiotics}

Group A bacteriocins. Resistant mutants of indicator strains were obtained against most of the $A$ bacteriocins apart from those which produced turbid areas of inhibition from which it was not possible to select mutants. Table 2 shows that the $\mathbf{A}$ bacteriocins can be differentiated into eight types by their activity on various resistant mutants. This division is supported by the results given in Table 3. Thus A6 is the only bacteriocin active on salmonellas, A1 and A3 are active on Aerobacter aerogenes $\mathrm{x}_{1}$, and bacteriocin A1 kills Escherichia coli ø. The bacteriocins of 40 of the 71 strains which produce the A substances have been subdivided. The remaining strains either produce the bacteriocin in low titres or they do not correspond to any of the eight subtypes.

Group $B$ bacteriocins. Resistant mutants selected from the indicator organism Hafnia $\mathrm{H}_{1}$ to the $\mathrm{B}$ bacteriocins produced by SM 5, 6, 9, NCTC 1377 were resistant to 
all other bacteriocins of group B. Resistant mutants of Escherichia coli ø to bacteriocins produced by SM $2,5,11,43,44,45$, NCTC 9940,9743 were also resistant to all the bacteriocins of group B. Strain SM 5 produced only a B bacteriocin; antiserum against this bacteriocin inactivates all the B-group agents. Antiserum was prepared only against the SM 5 bacteriocin. These results indicate possible identity of the group B bacteriocins produced by the 54 strains. There is one exception : the product of ATCC 9986 is similar to the other B bacteriocins by the above criteria, but E. coli strains were not susceptible.

Table 3. Spectrum activity of bacteriocins of Serratia marcescens

Inhibitory agent
$\mathbf{A}_{1}$
$\mathbf{A}_{\mathbf{2}}$
$\mathbf{A}_{\mathbf{3}}$
$\mathbf{A}_{4}$
$\mathbf{A}_{\mathbf{5}}$
$\mathbf{A}_{\mathbf{8}}$
$\mathbf{A}_{7}$
$\mathbf{A}_{8}$
$\mathbf{B}$
B (produced by ATCC $\mathbf{9 9 8 6}$ )

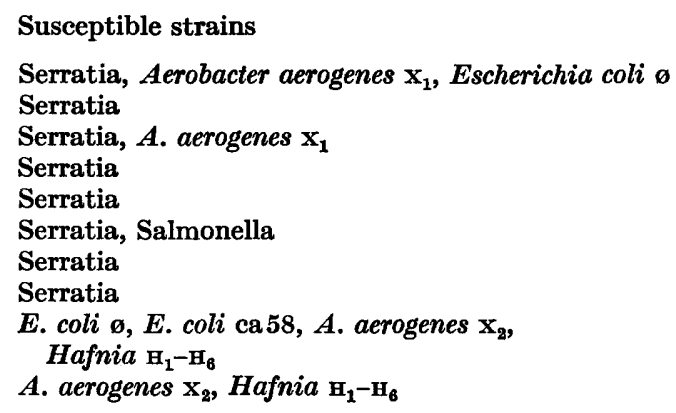

Distinction between colicins and bacteriocins $A, B$

Hafnia $\mathrm{H}_{1}$ was susceptible to the $\mathrm{B}$ bacteriocins and not to the various colicins. Serratia strains susceptible to the $A$ bacteriocins were not susceptible to colicins. Escherichia coli ø was susceptible to serratia bacteriocins B, A1 and all colicins. Colicin-resistant mutants of $\boldsymbol{E}$. coli ø were still susceptible to the bacteriocins B, A 1, except $\boldsymbol{E}$. coli ø mutants resistant to colicin $k$. These mutants were resistant to bacteriocin B, although susceptible, to bacteriocin A1. However, resistant mutants of $\boldsymbol{E}$. coli $\varnothing$ to bacteriocin B were susceptible to colicin K. Colicin K was not neutralized by antiserum to the bacteriocin B liberated by strain sM 5 .

\section{Lysogeny}

Strains SM 8, 37, 41, 56 liberated phage spontaneously in high titres $\left(1 \times 10^{9}\right)$. Phages derived from the first two strains were active on these strains. These phages may be virulent mutants of prophages carried by these organisms (Jacob \& Wollman, 1961) and capable of overcoming homologous immunity. The corresponding temperate phages have, however, not been demonstrated. Thirty-three out of the remaining 139 strains liberated phage spontaneously or after u.v.-induction. As in the case of inducible bacteriocins, mass lysis was never observed ind the turbidity readings simply increased with time. Cultures were u.v.-irradiated in various phases of the growth cycle for various periods of time. A period of 1 min. of u.v.-irradiation of an overnight culture usually gave maximal titres after $18 \mathrm{hr}$ incubation. Phages liberated by strains SM 8, NCTC 2847 had similar host ranges, and phages derived from strains SM $9,41,52$, ATCC 9986 were also similar by this criterion. The results are too unwieldy for presentation but the remaining 10 phages could be differentiated from one another by their host ranges, and 19 phages plated equally well on various serratias and salmonellas (Prinsloo \& Coetzee, 1964). The plaques which the 19 
phages formed on the 15 Salmonella strains were slightly turbid but attempts to lysogenize three of the Salmonella strains were uniformly negative and the clones remained sensitive to the phages.

Strains which produced phage and an A type bacteriocin often attacked a particular Serratia strain but these agents could invariably be distinguished by using additional indicator organisms. The phage and the bacteriocin type $\mathbf{A}$ produced by a single strain could also be distinguished by the selection of mutants of the indicator organism resistant to the bacteriocin. The phage was invariably still active on the mutant.

\section{DISCUSSION}

The trypsin-resistant and trypsin-sensitive bacteriocins described previously (Hamon \& Peron, 1961) correspond to the A and B bacteriocins described here. The bacteriocins described by Mandel \& Mohn (1962) are similar to our B agents. It has been confirmed that the trypsin-sensitive B bacteriocins do not attack Serratia marcescens and shown that some of the A subtypes also attack Escherichia coli, Aerobacter and Salmonella strains while the B group kill $\boldsymbol{E}$. coli, Aerobacter and Hafnia strains. Mandel \& Mohn (1962) showed that a mutant of $E$. coli Row which was resistant to colicin $\mathbf{K}$ was also resistant to the substances produced by their Serratia strains. They designated the latter substances sub-species of colicin $\mathbf{K}$. Colicin $\mathbf{K}$ resistant mutants of $\boldsymbol{E}$. coli ø are also resistant to bacteriocin $\mathrm{B}$ but it has been possible to differentiate between the latter and colicin $\mathrm{K}$. The two bacteriocins also have different electrophoretic mobilities (Prinsloo, Maré \& Coetzee, 1965). Hamon \& Peron (1961) demonstrated that $86 \%$ of their 85 Serratia strains were bacteriocinogenic. The investigation of Mandel \& Mohn (1962) showed $58 \%$ of 31 strains of $S$, marcescens to be bacteriocinogenic for $E$. coli strains. The figure found in the present work is $64.7 \%$ for 139 strains of $S$. marcescens. Our strains do not undergo clearing after u.v.-induction and resemble the colicinogenic strains of $E$. coli (Fredericq, 1955), a pyocin-producing strain of Pseudomonas aeruginosa (Hamon, 1956), and pestocinogenic strains of Pasteurella pestis (Ben-Gurion \& Hertman, 1958) in this respect.

Like the strains of Hamon \& Peron (1961) many of our strains produce more than one antibiotic material. This has been confirmed (Prinsloo et al. 1965) by the demonstration that the $\mathbf{A}$ bacteriocins are electrophoretically mobile, while $\mathbf{B}$ agents produced by the same strain are stationary. A particular Escherichia coli strain may produce two or more distinct colicins (Fredericq, 1958), individual strains of Enterobacter cloaca (Hamon \& Peron, 1962) are also believed to be multiple cloacinogenic, and strains of Salmonella typhimurium have been rendered doubly colicinogenic (Smith \& Stocker, 1962).

The mole \% guanidine + cytosine of the genera Serratia and Salmonella are 58 and $50 \%$, respectively (Marmur, Falkow \& Mandel, 1963). Despite this difference, 19 of the Serratia marcescens phages multiplied in various Salmonella species, but lysogenization by the serratia phages could not be demonstrated in salmonellas. Phages may multiply in bacteria with base compositions very different from their own (Lanni, 1960), and the present examples may only indicate that some Serratia and Salmonella strains share phage receptors (Meynell, 1964). 


\section{REFERENCES}

Adams, M. H. (1959). Bacteriophages. New York: Interscience Publishers Inc.

Amati, P. \& Ozeki, H. (1962). Transfer of colicinogenic factors to Serratia marcescens. In Abstr. VIIIth int. Congr. Microbiol. Montreal, p. 26. Montreal: Thérien Frères Limited.

Ben-Gurion, R. \& Hertman, I. (1958). Bacteriocin-like material produced by Pasteurella pestis. J. gen. Microbiol. 19, 289.

Coetzee, J. N. (1963a). Lysogeny in Proteus rettgeri and the host-range of $P$. rettgeri and $P$. hauseri bacteriophages. J. gen. Microbiol. 31, 219.

Coetzee, J. N. (1963b). Transduction of swarming in Proteus mirabilis. J. gen. Microbiol. 33, 1.

FredericQ, P. (1954). Transduction génétique des propriétés, colicinogènes chez Escherichia coli et Shigella sonnei. C. r. Séanc. Soc. Biol., Paris 148, 399.

Frederica, P. (1955). Induction de la production de colicine et de bacteriophages par irradiation ultraviolette de souches colicinogènes et lysogènes d'Escherichia coli. $C$. $r$. Séanc. Soc. Biol., Paris 149, 2028.

FredericQ, P. (1958). Colicins and colicinogenic factors. Symp. Soc. exp. Biol. 12, 104.

Fuller, A. T. \& Horton, J. M. (1950). Marcescin, an antibiotic substance from Serratia marcescens. J. gen. Microbiol. 4, 417.

Hamon, Y. (1956). Contribution à l'etude des pyocines. Ann. Inst. Pasteur 91, 82.

Hamon, Y. \& PEron, Y. (1961). Étude de la propriété bacteriocinogène dans le genre Serratia. Ann. Inst. Pasteur 100, 818.

Hamon, Y. \& Peron, Y. (1962). Sur la cinétique de la liberation de leur antibiotique pour les divers types de microbes bacteriocinogènes. C. r. hebd. Séanc. Acad. Sci., Paris 255, 2210.

JACOB, F. \& Wollman, E. L. (1961). Sexuality and the Genetics of Bacteria. New York: Academic Press.

Lanni, F. (1960). Genetic significance of microbial DNA composition. Perspect. Biol. Med. 3, 418.

Levine, M. (1957). Mutations in the temperate phage P22 and lysogeny in Salmonella. Virology 3, 22.

MANDEI, M. \& Mohn, F. A. (1962). Colicin groups of Serratia marcescens. In Abstr. VIIIth Int. Congr. Microbiol. Montreal, p. 26. Montreal: Thérien Frères Limited.

Marmur, J., Falkow, S. \& Mandel, M. (1963). New approaches to bacterial taxonomy. A. Rev. Microbiol. 17, 329.

Martinec, T. \& Kocur, M. (1961). The taxonomic status of Serratis marcescens. Int. Bull. Bact. Nomencl. Taxon. 11, 7.

MEYNELL, E. (1964). The significance of bacteriophage in bacterial classification. J. gen. Microbiol. 36, 461.

Prinsloo, H. E. \& Coetzee, J. N. (1964). Host-range of temperate Serratia marcescens bacteriophages. Nature, Lond. 203, 211.

Prinsloo, H. E., Mare, I, J. \& Coetzee, J. N. (1965). Agar electrophoresis of antibiotics produced by Serratia marcescens. Nature, Lond. 206, 1055.

Ryan, F. J., Fried, P. \& Mukor, F. (1965). A colicin produced by cells that are sensitive to it. Biochim., biophys. Acta 18, 131.

Smith, S. M. \& Stocker, B. A. D. (1962). Colicinogeny and recombination. Br. med. Bull. 18, 46 .

WAHBA, A. H. (1963). The production and inactivation of pyocines. J. Hyg., Camb. 61, 431. 